\title{
The New Politics of Religious Education in the United States and Germany
}

\author{
Amandine Barb*
}

(Received 20 August 2019; accepted 29 August 2019)

\begin{abstract}
This Article explores the contemporary governance of religious diversity in the United States and Germany through the case study of religious education in public schools. The United States and Germany have two very different approaches to teaching religion: The subject does not exist at all in American public schools, while in Germany, confessional religious education is explicitly mandated by the Federal Constitution and is still an integral part of the curriculum in the vast majority of Länder. Yet, both countries have recently been confronted with similar challenges - a growing diversification and politicization of religious identitieswhich have forced them to rethink the place and role traditionally given to faith in the sphere of public education. The Article thus examines how, and to what extent, the American and German historical models of religious education - and thereby, more broadly, the public governance of religion in both countrieshave been transformed by the changes in their religio-political landscapes.
\end{abstract}

Keywords: Religion; education; Germany; United States; Islam

\section{A. Introduction}

This Article intends to shed light on the contemporary governance of religious diversity in the United States and Germany by analyzing the recent changes in these two countries' respective approaches to teaching religion in public schools.

Germany and the United States are both federal states, and the politics of education are thus mainly the responsibility of the local authorities - the individual states in the United States ${ }^{1}$ and the Länder in Germany. Aside from federalism, the countries do not seem to have anything in common when it comes to the specific issue of religious education. In fact, the United States and Germany embody two very different models of religious education: The subject does not exist at all in American public schools - and is in fact prohibited by the Establishment Clause of the First Amendment ${ }^{2}$ — while in Germany, confessional-sectarian religious education is explicitly mandated by the Federal Constitution and is still today, in the vast majority of Länder, an integral

\footnotetext{
*Amandine Barb is a Research Fellow at the Lichtenberg Kolleg at the University of Göttingen. Between 2014 and 2018 , she was a researcher at the Humboldt University in Berlin. She received her PhD in Political Science from Sciences Po in Paris. Her first book, titled Between God and Caesar: A Political History of Religious Accommodations in the United States (Entre Dieu et César. Histoire politique des accommodements religieux aux États-Unis) was published in 2019 by Aix-Marseille University Press.

${ }^{1}$ In the United States, the content of educational standards is decided at the local level by the State Boards of Education of each individual state. The Board of Education — or, in some states, the school districts—-then issue a list of approved textbooks that have to match the educational standards.

${ }^{2}$ The religion clauses of the First Amendment, adopted in 1791, assert that: "Congress shall make no law respecting an establishment of religion [Establishment clause], or prohibiting the free exercise thereof [Free Exercise clause]"; Cantwell 
part of the curriculum. ${ }^{3}$ Yet, both countries have recently been confronted with similar challengesa growing diversification and politicization of religious identities, triggered in part by the emergence of assertive "public religions,"4 for example, Evangelical Christianity in the United States and Islam in Germany - which have forced them to rethink the place and role traditionally given to faith in their schools. This Article thus aims to explain how, and to what extent, the American and German historical models of religious education-and thereby, more broadly, the public governance of religion in both countries-have been affected and transformed by the changes in their religio-political landscapes.

The Article first retraces the introduction of courses about religion in American public schools since the 1980s. It then focuses on the debates over Islamic and interreligious education in Germany. This transatlantic comparison ultimately reveals that, in both cases, schools have become a medium through which American and German public officials not only try to manage the challenges brought up by a growing diversity, but also attempt to control and monitor religious identities, in order to make them compatible with the expectations of a secular democracy. ${ }^{5}$

\section{B. Education About Religion in the United States}

\section{I. (Re)introducing Religion as a Legitimate Subject of Study in American Public Schools}

Historically, religion did play an important role in the education of American citizens. Even after the adoption of the First Amendment to the Federal Constitution in 1791, and the subsequent disestablishment of official churches at the state level in the first half of the nineteenth century, the reading of the Protestant Bible and of the Ten Commandments, as well as non-denominational prayers, remained mandatory in the vast majority of schools. The influence of religion in American public education began to decline at the end of the nineteenth century as religious exercises gradually disappeared from the classroom. For instance, a report written by Columbia Teachers College in 1912 explained that in schools across the country, "religious instruction is either entirely eliminated or else reduced to the ... most formal elements." 6 The secularization of American public education became fully realized after the Supreme Court extended the scope of the First Amendment to the individual states in the 1940s: Religious instruction ${ }^{7}$ and mandatory prayers ${ }^{8}$ were ruled

v. Connecticut, 310 U.S. 296 (1940); Everson v. Board of Education, 330 U.S. 1 (1947) (interpreting the Religious clause of the First Amendment as requiring a separation between religion and the state at both the federal and local levels).

${ }^{3}$ Article 7 of the Basic Law for the Federal Republic of Germany, adopted in 1949, states that:

(2) Parents and guardians shall have the right to decide whether children shall receive religious instruction.

(3) Religious instruction shall form part of the regular curriculum in state schools, with the exception of non-denominational schools. Without prejudice to the state's right of supervision, religious instruction shall be given in accordance with the tenets of the religious community concerned.

For a comparative analysis of the American and German models of religion/state relations, see CLAUDIA E. HAUPT, RELIGIONState Relations In The United States And Germany: The Quest For Neutrality (2012); Johannes Zachhuber, Religion and Politics in the United States and Germany: Public Lecture at the Beyers-Naudé Centre of Public Theology (Dagmar Pruin et al. eds., 2007); Edward J. Eberle, Church And State In Western Society: Established Church, CoOperation And SEPARATION (2011). For a more specific focus on Protestant religious education, see Richard R. OSMER \& FrIEDRICH Schweitzer, Religious Education Between Modernization And Globalization: New Perspectives On The United States And Germany (2003).

${ }^{4}$ José Casanova, Public Religions in the Modern World (1994).

${ }^{5}$ For a more general comparative literature on the transformations of religious education in contemporary democracies, as well as on the underlying political issues, see Religious Education And The Challenge Of Pluralism (Adam B. Seligman ed., 2014); Religious Education At Schools In Europe, Vol.1 (Martin Jäggle, Martin Rothgangel, Thomas Schlag eds., 2014); Religious Education Politics, The State, And Society (Asgar Jödicke ed., 2013).

${ }^{6}$ Steven K. Green, The Bible, the School, and the Constitution: The Clash that Shaped Modern Church-State DOCTRINe 12 (1st ed. 2012).

${ }^{7}$ McCollum v. Board of Education, 333 U.S. 2013 (1948).

${ }^{8}$ Engel v. Vitale, 370 U.S. 421 (1962). 
unconstitutional, as well as the devotional reading of the Bible, ${ }^{9}$ and the teaching of creationism in biology classes. ${ }^{10}$ The state-whether local or Federal—could no longer favor one belief over another, or even religion over non-religion, as this bore the risk of making atheists or followers of minority faiths feel as second-class citizens. These decisions did not mean, however, that any reference to religion had to be categorically kept out of public schools. On the contrary, the Supreme Court explicitly held that a non-devotional and strictly academic approach to studying religion or the Bible was constitutional. Yet, as a result of the Court's First Amendment jurisprudence, religion as a subject of study also became largely overlooked in public schools across the country. In addition to being considered too controversial, religion was discarded as irrelevant for the education of democratic citizens in a world thought to become more and more secularized due to advances in technology and science.

Given this suspicion or disinterest towards religion in American schools, why, starting at the end of the 1980s, was it reconsidered as an important aspect of public education? This development was first the result of the resurgence of what José Casanova has called "public religions"namely conservative Evangelical Christianity_in the United States. ${ }^{11}$ The so-called "Christian Right"-which was then emerging as a political force under Ronald Reagan's first presidencyregularly asked lawmakers and judges across the country to legally reinstate the Bible, prayers, and creationism in the classroom. On the one hand, conservative Christians thus contributed to turning the topic of religion and education into an important public issue during that period. ${ }^{12}$ On the other hand, the absence of religion in the curricula was also criticized by progressive organizations who supported the project of a multicultural education. The main goal of this pedagogical reform - introduced in the 1960s — was to better consider the history and contributions of ethnic and racial minorities, as well as women, in the public school curriculum. The multicultural turning point of public education had so far ignored religion in education until the 1980s, when scholars, educators, and progressive interest groups started to ask for its inclusion into educational standards. American society needed to adapt to the changes in its religious landscape: The 1965 Immigration and Nationality Act, which removed the restrictions on immigration from Asia and the Middle East, had indeed led to a significant increase in the number of non-Christian minorities in the United States, notably Muslims, Hindus, and Sikhs. ${ }^{13}$

At the end of the 1980s, against this backdrop of a growing diversification and politicization of faith, state Boards of Education - supported by scholars, educators, religious lobbies, and church and state separation advocacy groups - started to introduce new courses about religion in public schools. In 1988, California was one of the first states to make teaching about religion compulsory in middle school history curricula. In 1995, the Clinton administration signed the Federal Guidelines on Religion in Public Schools into law, making clear to every school district in the country that "public schools [can] teach about religion ...", and that "comparative religion, the Bible as literature, and the role of religion in the history of the United States and other countries are permissible school subjects." 14

In every American state today, world history and world geography curricula require students to learn about the characteristics of major world religions, as well as about their cultural, social, and political influences. The religions studied in American public schools are mainly Judaism, Christianity, Islam, Hinduism, and Buddhism. US history courses also include references to

\footnotetext{
${ }^{9}$ Abington v. Schempp, 374 U.S. 203 (1963).

${ }^{10}$ Epperson v. Arkansas, 393 U.S. 97 (1968); Edwards v. Aguillard, 482 U.S. 578 (1987).

${ }^{11}$ José Casanova, Public Religions in the Modern World (1994).

${ }^{12}$ Daniel K. Williams, God's Own Party: The Making of the Christian Right (2010).

${ }^{13}$ See A Nation Of Religions: The Politics Of Pluralism In Multireligious America (Stephen Prothero ed., University of North Carolina Press 2006).

${ }^{14}$ U.S. Dep't of Educ., Federal Guidelines on Religious Expression in Public Schools 12 (1998) [hereinafter Fed. Guidelines Relig. EXPRESSION Pub. SCHOOLS].
} 
important religious figures and movements, as well as to minority faiths and to the role of AfricanAmerican churches under slavery. It is thus not religious education per se-as it is in Germanybut rather it is education about religion, taught transversally, from a strictly academic, non-devotional, and non-sectarian perspective. ${ }^{15}$

Texas, Texas Essential Knowledge \& Skills, High-school, World History Studies (starting with school year 2011-2012):

The student is expected to: (A) describe the historical origins, central ideas, and spread of major religious ... traditions, including Buddhism, Christianity, Confucianism, Hinduism, Islam, Judaism, Sikhism, and the development of monotheism, and (B) identify examples of religious influence on various events in ... World History. ${ }^{16}$

California, History-Social Science Framework, Chapter 10, World History, "Medieval and Early Modern Times" (adopted in 2016):

How did major religions (Judaism, Christianity, Islam, Buddhism, Hinduism, and Sikhism) ... develop and change over time? ${ }^{17}$

\section{The Promotion of "Democracy-Friendly" Religions Through Public Education}

Thus, after decades of avoiding religion in the classroom, the diversification and politicization of faith have triggered a change in consciousness among state officials, scholars, educators, and interest groups. The latter grew aware of the resilience of religious identities in the public sphere. As a result, religion has come to be reconsidered as an important resource for the education of citizens within a pluralistic American democracy. In that sense, courses about religion-as they have been introduced across the country since the 1980s-carry a clear civic objective. They are intended to increase awareness of religious differences and to foster intercultural understanding among students. According to the National Council for the Social Studies - which develops educational standards for history and geography_these courses are intended to "decreas[e] religious illiteracy and the bigotry and prejudice it fuels," and thus to foster an "effective and engaged citizenship in the nation and the world." 18

It could be further argued that the content of courses about religion in the United States reflects a specific, democracy-friendly approach towards faith-one that could be characterized as a "civilized pluralism." This normative narrative, which "reflects how religious differences should be apprehended by students ... favors moderate, reflexive and ecumenical religions, and highlights examples of interfaith encounters, while downplaying instances of conflicts and violence." 19 State educational standards, for example, stress the positive relationships between diverse religious traditions: California invites history teachers to "emphasize the common features" between Christians, Muslims, and Jews, as well as "the many ways in which [they] interacted." 20

\footnotetext{
${ }^{15}$ See Bruce Grelle, The First Amendment and the 3Rs of Religious Liberty: A US Approach to Religion Education and Human Rights, in Human Rights and Religion in Educational Contexts 243-55 (Manfred L. Pirner et al. eds., 2016).

${ }^{16} 19$ Tex. Admin. Code $\$ \$ 113.40-113.50(2010)$.

${ }^{17}$ Cal. Dep't Of Educ., 2016 History-Social Science Framework For California Public Schools 180 (July 2016) [hereinafter History-Social SCI. Framework Cal. Pub. Schools].

${ }^{18}$ National Council for the Social Studies, Religious Studies Companion Document for the C3 Framework, in C3 FRAMEWORK FOR SOCIAL STUdies STATE STANDARDS 92-97 (2017), available at https:/www.socialstudies.org/sites/default/files/2017/Jun/ c3-framework-for-social-studies-rev0617.pdf.

${ }^{19}$ Amandine Barb, Governing Religious Diversity In a (Post)Secular Age: Teaching about Religion in French and American Public Schools, 16 Theo-Web ACAD. J. Religious Educ. 204, 210 (2017) (emphasis in original).

${ }^{20}$ History-Social Sci. Framework Cal. Pub. Schools, supra note 16.
} 
In Texas, standards for world history require students to learn about the "interactions among Muslim, Christian, and Jewish societies in Europe, Asia and Africa," or about the "interactions between Muslim and Hindu societies." 21 Similarly, a survey of world history textbooks shows that they strongly emphasize the three Abrahamic faiths' shared values and theologies and draw parallels between the Koran, the Hebrew Bible, and the Christian Bible. The textbooks also emphasize the three religions' "sites of encounters" and instances of peaceful "cooperation" and "connections." 22

Yet one must also note that, despite recent initiatives aimed at fostering the teaching of religion in American public schools, these courses are still often limited to a mere presentation of religious facts mainly taught from a historical perspective. In most states, there is also a lack of systematic training for teachers. The discrepancies between the civic objectives assigned to these courses and their actual implementation-explained in part by the legal burdens of the First Amendmenteventually question the extent to which a constitutionally secular state can engage with religion and foster a normative pluralism via the sphere of public education. ${ }^{23}$

\section{Courses About Religion as a Political and Identity Issue}

Moreover, the ambition of an academic and pluralistic approach to religious diversity in the classroom is further complicated by the fact that teaching about religion in the United States has also become a contentious political and identity issue in recent years. Accordingly, religious interest groups actively attempt to influence the design and implementation of courses about religion, which sometimes triggers conflicts with public officials, educators, and scholars. These advocacy groups - whose main objective is to defend the rights and the social and political interests of people who identify as members of their religious community-are involved at all stages of the adoption process of both state educational standards and textbooks: They petition the Boards of Education, send hundreds of comments to the Boards and publishers when standards and textbooks are released to the public before their official adoption during the phase of public review, and sometimes even sue the Boards and publishers over what they consider an improper depiction of their faith.

Non-Christian minority religions in particular-Muslims, Hindus, and Sikhs—-have made the introduction of courses dedicated to their faith in public school curricula an important part of their identity strategies. Textbooks provide them with a unique medium to accustom generations of citizens to their beliefs, but also to display an attractive public image by countering stereotypes and emphasizing the compatibility of their values with those of American society. The creation of lobbies was specifically dedicated to monitoring and influencing educational standards and textbooks. These lobbies included the Hindu Education Foundation and the Council on Islamic Education, for example, while some broader advocacy groups-such as the Hindu American Foundation and the Council on American-Islamic Relations-have also made education one of their main focuses in recent years.

Over the past decade, for instance, the Sikh Coalition-the main Sikh-American interest group-has managed to convince Boards of Education in California, Texas, Arizona, Colorado, Idaho, New Jersey, New York, and Tennessee to make the study of Sikhism compulsory in these states' schools. By ensuring that millions of students will learn about their beliefs, the objective of the Coalition is to promote a "cultural shift in the minds of Americans" so that "future generations of Sikhs will be appreciated" in the United States. ${ }^{24}$

\footnotetext{
${ }^{21}$ TeX. Admin. CoDE $\$ \$ 113.40-113.50$, supra note 15.

${ }^{22}$ Barb, supra note 18.

${ }^{23}$ Barb, supra note 18 .

${ }^{24}$ Including Sikhism in State Curriculum Standards, SIKH COALITION (2019), https://www.sikhcoalition.org/ourwork/ creating-safe-schools/including-sikhism-in-state-curriculum-standards.
} 
Yet, religious minorities not only want to be included into educational standards and textbooks, They also see courses about their religion as an opportunity to control and shape the public narrative on their beliefs and identity. They thus directly attempt to influence the content of educational materials. In that respect, religious interest groups particularly target what they consider to be negative descriptions, stereotypical iconography, or the use of complicated concepts that could be hard to understand for most American students. Hindus, for example, have systematically rejected the characterization of their faith as polytheistic or pantheistic, suggesting to Boards of Education and publishers that they would rather describe their theistic system as being dominated by a Supreme Being, a more common concept in the American context. More generally, minorities aim to stress the civic virtues of their faith, ${ }^{25}$ refusing to be associated with instances of violence and intolerance or with poor treatment of women. In a letter sent to the Colorado Department of Education prior to the adoption of the 2018 educational standards, the Sikh Coalition wrote that "nondiscrimination is a central focus of the Sikh religion, [which] explains why the founders of Sikhism rejected the caste system, gender inequality, and religious exclusivity." ${ }^{26}$ In 2016, the Sikh Coalition also asked the California Board of Education to explicitly mention in educational standards the fact that "Sikhism is ... based on the belief in one God and the equality of all human beings," and the "rejection of the caste system." 27

But the pluralistic ambitions assigned to courses about religion are also being challenged today by the "Christian Right." Since the 1960s, religious conservatives have been unsuccessful at reversing the Supreme Court's secularization of American public education, failing to bring back the Bible, prayers, or the teaching of creationism into the classroom. In recent years, however, they have strategically used the new emphasis on religion in school curricula as an opportunity to rehabilitate the place of Christianity in the civic imaginations of American citizens. On the one hand, they have attacked the positive treatment of religious diversity in textbooks, questioning in particular the way Islam is portrayed. In several states, for example, they have called for the boycott of world history textbooks or brought lawsuits against teachers, school districts, and publishers accused of promoting Muslim beliefs while marginalizing Christianity. ${ }^{28}$ On the other hand, religious conservatives also seek to promote a distinct Christian worldview in the curricula. In 2015, for instance, the Texas Board of Education - where seven members out of fifteen self-identified as Christian conservatives - adopted new textbooks for high school US history courses in accordance with the educational standards drafted five years earlier. Strongly criticized by church and state separation advocacy groups, these textbooks reflect the traditional conservative narrative about the United States as a Christian nation. The textbooks mention the "importance of JudeoChristian tradition" for the "American founding," with a specific emphasis on "biblical law," while Moses is presented as one of "the individuals whose principles of laws informed the American founding documents." 29

The claims and mobilizations of religious interest groups-whether minorities or conservative Christians-illustrate how the public governance of religion in the United States is a conflicted process, shaped by the interplay and negotiations that take place between diverse state and nonstate actors. These groups also defend, through their positions on faith and education, competing representations of the country's collective identity.

\footnotetext{
${ }^{25}$ Prema Kurien, Mr. President, Why Do You Exclude Us from Your Prayers? Hindus Challenge American Pluralism, in A Nation of Religions: The Politics of Pluralism in Multireligious America 119, 120 (Stephen Prothero ed., 2006).

${ }^{26}$ Letter from The Sikh Coalition to the Colorado Department of Education (Sept. 20, 2017).

${ }^{27}$ CA Sikh History Approved, Sets Precedent for Nation, SIKH COALITION (July 15, 2016), https://www.sikhcoalition.org/blog/ 2016/ca-sikh-history-approved-sets-precedent-for-nation-2.

${ }^{28}$ Barb, supra note 18.

${ }^{29}$ TeX. Admin. Code $\$ \$ 113.40-113.50$, supra note 15.
} 


\section{The Transformations of Religious Education in Germany}

As previously mentioned in the introduction, the approach to teaching religion in German public schools is very different from the American experience. Yet the core challenges facing German educators, scholars, and public officials are fundamentally the same as in the United States. These challenges include how to better take into account the growing diversity of the population, how to better integrate minorities - especially Muslims - and how to prevent conflicts and religious fundamentalism. In other words, how to adapt the traditional model of religious education to the complex realities of a multi-faith democracy in a globalized world at the beginning of the twenty-first century.

Religious education in Germany has a special constitutional status, because Article 7-3 of the Basic Law requires Länder to provide courses on religion in public schools as a "regular part of the curriculum" in accordance with the relevant religious communities. ${ }^{30}$ Even more remarkable is the fact that religious education is the only school subject that is explicitly mandated by the Federal Constitution. Today, every Land offers religious education in its public schools, although they do not all have the same approach to the topic. Most schools provide a choice of either Protestant or Catholic denominational, confessional education. Students who do not wish to participate in these courses - or parents who object to them - may opt out, but they then have to take an alternative ethics course, sometimes called "Values and Norm"—Lower Saxony—or "Practical Philosophy"-North-Rhein Westphalia.

A few exceptions to this mandatory religious education are allowed by the so-called "Bremen Clause" of the Basic Law. The Clause provides that regulations requiring compulsory confessional religious education must not apply to those Länder where "another state law regulation was in existence on January 1, 1949.” Although most east German Länder-where religion had been completely excluded from public schools under the communist regime-made religious education mandatory after the Reunification in 1990, this is not the case in Berlin. There, confessional religious education is only provided as an optional, extracurricular course, but students have to take a class called LER_Lebensgestaltung-Ethik-Religionskunde-in which they study ethics and comparative religions.

How, and to what extent, does the diversification and politicization of religion influence and transform this approach to religious education in Germany? It can be argued that there are two parallel trends today. On the one hand, there have been attempts to include non-Christian religions-particularly Islam-but without changing the traditional model of religious education, for example, by introducing confessional Islamic education alongside the already existing Protestant and Catholic courses. The other trend, the other method gives up the confessional, sectarian system of religious education entirely in order to replace it with a more inclusive and interfaith approach to teaching religion.

\section{The Difficult Integration of Islam into a Structurally Unequal, Christian-Dominated System of Religious Education}

If reunification had initially raised questions for the future of religious education in Germany, the most important challenges today, however, are those triggered by Islam. Since the 1970s and 1980s, Muslim organizations have repeatedly asked for equal treatmentaccording to Article 7-3 of the Basic Law, so they can provide Islamic education in public schools alongside Catholics and Protestants. This is of course an issue of right-being granted the same opportunities as members of other religious groups-but it is also, more generally, an issue of inclusion and recognition. The institutionalization of Islamic education in public schools would signal that Muslims, whose number is constantly increasing - they are now about $6 \%$ of the population ${ }^{31}$ - are

\footnotetext{
${ }^{30}$ supra note 3.

${ }^{31}$ Religion \& Public Life, The Growth of Germany's Muslim Population, PEW ReSEARCH CENTER (Nov. 29, 2017).
} 
officially acknowledged as an important part of contemporary German society, not simply perceived as foreigners or migrants, bound to eventually go back to their respective countries. In 1984, the Education Ministers of the various Länder-Kultusministerkonferenz-agreed that, given the growing number of immigrants in Germany, Islamic education needed to be included in public schools. ${ }^{32}$ But, despite the growing assertiveness, organization, and mobilization of Muslims, the inclusion of Islamic education into German public schools has been a very slow process until today. The case of Islam thus testifies to the deep inequalities at the heart of the German system of religious education, which is structurally biased towards Christian churches.

Accordingly, if the Basic Law of 1949 provides for freedom of faith and conscience and prohibits the establishment of an official church in Germany. But the state is, in practice, not completely neutral towards religion as a special partnership exists between the government and Christian churches via the legal status of Public Law Corporation-Körperschaftsstatus (PLC) - that is granted to some religious groups. The PLC status was first established by the Weimar Constitution, adopted in 1919, and Article 137 states that:

Religious associations have the right to incorporate according to the general provisions of the civil code. Religious associations shall, to the extent that they were formerly, remain public corporations. The same rights may be accorded to other religious associations if, by their constitution and the number of their members, they give assurance of permanence .... Religious associations which are public corporations are entitled to levy taxes on the basis of the civil tax lists in accordance with provisions of the laws of the states. ${ }^{33}$

Accordingly, therefore, a religious community that is a PLC can indirectly collect taxes through the state, but also appoint prison, hospital, and military chaplains. Furthermore, the status of PLC gives access to public funding for hospitals or religious schools. Being a PLC, however, is particularly crucial when it comes to religious education, as only legally recognized groups can offer instruction in public schools, participate in accredited teacher training programs in public faculties of theology, and have the salaries of teachers paid by the state. This close relationship between the state and religious communities has been characterized as a "positive accommodation model of democratic secularism" by political scientist Alfred Stepan. He further describes this arrangement as a "historically constructed and negotiated, often consociational, bargain" between Christian churches and public authorities. ${ }^{34}$

In that context, therefore, it is not surprising that this PLC status has precisely been the main legal and institutional obstacle for minorities willing to cooperate with the state and to teach their religion in German public schools. According to the Basic Law, the decision to grant the PLC status is made at the local level, by the Länder, which base their assessment on a number of specific criteria, including an assurance of the group's permanence, size, and respect for the constitutional order and fundamental rights of individuals. These criteria, which fit the history and organizational model of the Catholic and Protestant churches, ${ }^{35}$ have proved very problematic for minorities, especially for Muslims who are not as institutionalized as Christian groups, do not have a central authority, and are often divided into several branches. As Stepan sums it up:

\footnotetext{
${ }^{32}$ Sylvie Toscer-Angot, L'enseignement religieux islamique en Allemagne depuis les années 1980: de la déterritorialisation à l' inclusion, in 2 ALLEMAGNe D'AUJOURD'HUi 215-27 (2016).

${ }^{33}$ Weimarer Verfassung [Constitution] Aug. 11, 1919 (Ger.) (replaced in 1949 by Grundgesetz FÜr Die Bundesrepublik Deutschlan [Basic Law] May 8, 1949).

${ }^{34}$ Alfred Stepan, The Multiple Secularisms of Modern Democratic and Non-Democratic Regimes, in RETHINKING SECUlarism 20 (Craig Calhoun et al., eds., 2011); see also HAupt, supra note 3; J. Christopher Soper et al., Germany: Church-State Partnership, in The Challenge of Pluralism: Church and State in Six Democracies 193-228 (2017).

${ }^{35}$ Most Protestant churches in Germany are grouped into a federation called Evangelische Kirche in Deutschland (EKD).
} 
New immigrants, such as Muslims, in principle, could be included in such accommodation, but much of the positive accommodation has historically been developed by the European states' tradition of treating religions as hierarchical legal bodies that qualify as public corporations that can enter into legal agreements with state authorities .... [F] rom the German state's perspective Muslims do not yet qualify as a public corporation for reasons mainly of their internal diversity which makes them difficult to fit into long-standing German law. ${ }^{36}$

Some Alevite groups did manage to obtain PLC status, but until the turn of the twenty-first century, requests made by most Muslim communities had been almost systematically rejected, thus de facto restricting their rights and influence within German society and, more particularly, in the sphere of public education. This situation has slowly begun to evolve over the past few years. The rise of a global and political Islam; 9/11 and other terrorist attacks perpetrated by extremist Muslim groups; the fact that hundreds of young Germans chose to join the ranks of ISIS in Syria and Iraq; and the arrival of close to one million refugees from the Middle East in Germany since 2015. These developments have made German public authorities aware that it was in their best interest to develop a close partnership with Muslim communities and, more particularly, to foster Islamic education courses in public schools in order to better monitor, and even influence, what is being taught to young German Muslims.

As theologian Rolf Schieder explains it, religious education in Germany carries an intrinsic civic mission. The state has historically used Christian religious education as a means to foster a civil religion - to fight religious fundamentalism, intolerance, and separatism, and to turn young believers into respectful, open-minded, and pluralist citizens. ${ }^{37} \mathrm{How}$, according to Schieder, is that "civilizing" of religion made possible, despite the constitutional requirement for state neutrality towards religious groups? This is done in an implicit manner by controlling the training of religious education teachers. They study for many years at departments of theology of public universities that are largely independent from churches where they critically learn about their own religion, are taught to interpret the texts by themselves, to develop their own opinion, and to not blindly follow the teachings of a higher authority. As Schieder puts it, religious education teachers:

who received their training at theological faculties are exposed to a plurality of theologies ... and to a plurality of spiritual behavior. This forces them to realize that their own way of believing is just one among many .... They are able to respect and embrace different perspectives and positions even when it comes to matters of faith and belief. ${ }^{38}$

As a result, religious education in public schools is different from what children learn with their family or at their place of worship. Historian Jean-Paul Willaime similarly explains that public schools, because of their very nature and specific requirements, almost automatically "include[] [the] religious facts [they teach] in the citizenship of pluralist democracies," and thus help to

\footnotetext{
${ }^{36}$ Stepan, supra note 33; Joyce M. Mushaben, Educating for Citizenship? Re-Assessing the Role of Islamic Instruction in German Schools, 3 Pol. \& Religion 518-52 (2010); J. Christopher Soper \& Joel S. Fetzer, Muslims and the State In Britain, France, ANd Germany (2005); Riva Kastoryano, Religion and Incorporation: Islam in France and Germany, 3 InT'L Migration ReV. 1234-55 (2004) (regarding the challenges faced by Muslim associations seeking to obtain the PLC status).

${ }^{37}$ Rolf Schieder, Religious Education in Germany: Civilizing Religion in Public Schools, Religious Educ. Pol., The STATE \& Soc'Y 85-101 (2013); Rolf Schieder, Tradition durch Innovation. Das System religiöser Bildung in Deutschland vor neuen Herausforderungen, Bildung In Der PostsäKularen Gesellschaft 199-210 (Stefan Müller \& Wolfgang Sander eds., 2018); Religious Education in Germany: A Model for the Future?, Religion And Politics In The United StATES And GERMANY 91-102 (2007).

${ }^{38}$ Schieder, supra note 36 , at 95 .
} 
"objectivize" and civilize religious identities. ${ }^{39}$ Religious education courses in public schools show students that their beliefs can be an object of scrutiny and examination, and thus "contribute to the epistemic ability to consider one's own faith reflexively." 40

Accordingly, as Schieder also argues, it is in the best interest of the German state today to provide a space for Islam in public schools. In that way-and as it is already the case with Catholic and Protestant religious education - the state could better control the content of courses and the training of teachers, prevent fundamentalism and foreign influences, and promote liberal, democratic values among Muslim children. Therefore, a greater institutional recognition of Islam in Germany, and the inclusion of Muslim communities within the positive accommodation framework of religion-state relations - notably through the expansion of Islamic education in schoolsis no longer the particularistic, undue demand of a foreign minority but has become, in the eyes of many, a crucial political and civic necessity. In 2008, for example, Wolfgang Schäuble-thenMinister for the Interior-officially acknowledged that an Islamic religious instruction, consistent with Article 7-3 of the Basic Law, should be introduced in public schools across the country. ${ }^{41}$ Over the past decade, a growing number of Muslim groups have been effectively granted the status of Public Law Corporation, thus enabling them to provide Islamic religious education. As a result, the number of Islamic religion classes has significantly increased all over Germany. Länder with existing programs of Islamic education — such as Rhineland-Palatinate, Baden-Wuerttemberg, Bavaria, North-Rhein Westphalia, Lower-Saxony, Berlin, and Hessen-have recently announced plans to expand Islamic religion courses to additional grade levels and schools. Many of those Länder directly cooperate with local Muslim communities to develop their course offerings and to draft the curricula.

Yet, the institutionalization of Islamic religious education in German public schools is bound to be a long-term process, notably for practical reasons: There is a need for more faculties of Islamic theology to properly train the growing number of school teachers, and these faculties in turn need to hire scholars of Islamic theology, of which they are currently very few in Germany. In 2010, the Federal Ministry of Education and Research-Bundesministerium für Bildung und Forschungdecided to support the establishment of centers for Islamic Theological Studies at several universities by creating professorships and junior research groups, for example. According to the official guidelines, these centers are intended to become "internationally recognized places of Islamic theological research that educate and promote scholars of Islamic Theology to be later employed at schools and universities." 42 The centers will be funded by the Federal government and the Länder. Currently, Islamic theological studies exist at the Universities of Tübingen, FrankfurtGiessen, Münster-Osnabrück, and Erlangen-Nürnberg. In 2018, Humboldt University in Berlin announced the establishment of the Berlin Institute for Islamic Theology- "BIT."to officially open in the Winter semester of 2019/2020. The BIT will be responsible for training imams, theologians, and religious education teachers. It was developed in collaboration with scholars and members of the Berlin Senate, as well as with the largest Muslim associations in the city. In that respect, the University purposely sought to have different Muslim sensibilities represented within the BIT's Advisory Board so as to maintain a position of neutrality and, more generally, as a way to fulfill the mission of the Institute: To "emphasize[] a theology of diversity" and "in particular [to] give due consideration to Sunni and Shia teachings in comparison." ${ }^{3}$ Yet, the decision to

\footnotetext{
${ }^{39}$ Jean-Paul Willaime, Religious Education in French Schools, in RELIGIOUs EdUCATION At SchOols In EuROPE, supra note 5 , at 116

${ }^{40}$ Jürgen Habermas, Religion in the Public Sphere, 14 EUR. J. PHIL. 9-10 (2006).

${ }^{41}$ Charles Hawley, Germany's Difficult Debate with its Muslim Community, Der SPIEgel (Mar. 14, 2008).

${ }^{42}$ Profile of the Institute, Goethe University Frankfurt Am Main Institute For The Study Of Islamic Culture And RELIGION, https://www.goethe-university-frankfurt.de/60291328/Profile_of_the_Institute.

${ }^{43}$ Senate Chancellery-Higher Education \& Humboldt-Universtät zu Berlin, The Members of the Advisory Board of the Berlin Institute for Islamic Theology Have Been Named, HumBoldT-Universtät Zu BERLIN (Mar. 26, 2019), https://www.hu-berlin. de/en/press-portal/nachrichten-en/march-2019/nr-19326.
} 
invite a representative of the Islamic Association of Shiite Communities of Germany to be part of the Advisory Board, although the organization is allegedly close to groups monitored by the German intelligence services, was decried by liberal Muslim figures, as well as by CDU and Green politicians, who argued that the presence of a "conservative" organization within the Board contradicts what should be one of the main goals of the BIT: To counter and prevent religious extremism. ${ }^{44}$

\section{Towards an "Integrative," Interdenominational Religious Education in German Public Schools?}

Beyond the inclusion of Islamic religious instruction, other initiatives have emerged in recent years in order to adapt Germany's system of religious education to an increasingly diverse society. Some have suggested replicating what has been done in Canada and other European countries: Abandoning the confessional, sectarian, and Christian-dominated model of religious education in favor of what Wanda Alberts has called an "integrative" approach to teaching religion. ${ }^{45}$ In that case, religious education courses would still be mandatory and part of the regular school curriculum, but it would be interfaith, taught mainly in an academic perspective, and thus inclusive of all students, who would not be separated along religious lines anymore. Today, this trend remains marginal in Germany, although there have been a few experiments with integrative religious education. Since the 1990s, for example, the Land of Hamburg has provided a course called "Interreligious Religious Education" or "Religious Education for All," instead of the traditional Protestant and Catholic classes. The goal of this course, which was initiated by the Evangelical Lutheran Church, is to foster dialogue about differences and diversity among students. The decision to replace the sectarian classes with a more inclusive, interfaith education was made because of the very diverse religious landscape of the Land of Hamburg, which houses a significant migrant population, and where more people identify as religiously unaffiliated than as Protestants. In Hamburg, non-Christian religious groups-Jews, Muslims, and Buddhistsdirectly contribute to the religious education curriculum, teaching materials, and training programs for teachers.

Is it possible to assert, however, that this type of interfaith course will become the norm in Germany, and that the country will at some point definitely move away from a denominational approach to religious education, towards an integrative model? This is unlikely to happen in the short to medium term, as the influence of Christian churches remains too strong. It is not surprising, in that respect, that both the Catholic and the Protestant leaderships in Germany have supported the inclusion of Islamic education in public schools: It allows them to deflect the debates over whether to give up the entire confessional, sectarian system of religious education in favor of an academic and comparative "religious culture education" for all, based on a phenomenological approach to the study of religion. ${ }^{46}$ Arguably, this latter model—successfully adopted in Québec, England, and Scandinavia, for instance-would certainly make it easier to integrate minorities and would be better suited to a pluralistic, secular democracy, where the number of non-Christians, unaffiliated citizens, and non-believers keeps increasing. But it is also a model of religious education that does not give much space or power to religious communities. In that sense, the expansion of confessional Islamic education in Germany is what paradoxically contributes today to the preservation of influence of Christian churches in public schools across the country, as well as, to their special and historical relationship with the state.

\footnotetext{
${ }^{44}$ Islamic Theology Institute at Berlin's Humboldt University Sparks Criticism, DeutsCHe Welle (June 30, 2018), https:// www.dw.com/en/islamic-theology-institute-at-berlins-humboldt-university-sparks-criticism/a-44466641.

${ }^{45}$ Wanda Alberts, Integrative Religious Education In Europe: A Study-Of-Religions Approach (De Gruyter ed., 2007); see also Martin Rothgangel et al., supra note 5.

${ }^{46}$ Charlene Tan, The Teaching of Religious Knowledge in a Plural Society: The Case for Singapore, 54 INT'L REV. EDUC. 175-91 (2008).
} 


\section{Conclusion}

Although the historical experience and legal framework are both different in Germany and the United States with regards to religion-state relations, both countries have attempted over the past decades to update and adapt their respective models of secularism to the new challenges of a multi-faith and globalized society. In that context, by introducing or expanding religious education in schools, American and German public officials have aimed to achieve several broader political goals: Fostering the integration of non-Christian minorities; promoting tolerance and interfaith understanding; and controlling, disciplining, and civilizing religions in order to contain their extremist and illiberal edges. Yet, and even though it is still too early to assess the broader impact of these reforms, it is also evident that the weight of historical and institutional pathdependencies remains strong in both countries. In the United States, the secular ethos of public education continues to be pervasive today, and, therefore, religion as a subject of study occupies a marginal place, mostly confined to a few chapters in history courses. Likewise, in Germany, despite the growing recognition of Islam, the broader framework of confessional, sectarian religious education - based on the historical arrangement between the state and Christian churchesalso endures as virtually unchanged. These realities ultimately question the United States' and Germany's inclusive and pluralist ambitions when it comes to the governance of religious diversity, particularly in the context of public schools.

Cite this article: Barb A (2019). The New Politics of Religious Education in the United States and Germany. German Law Journal 20, 1035-1046. https://doi.org/10.1017/glj.2019.73 